\title{
Postfoucaultowska analiza dyskursu o edukacji. Uwagi warsztatowe ${ }^{*}$
}

\section{KEYWORDS}

postfoucauldian discourse analysis, Michel Foucault, discourse on education, middle school (Poland)

\begin{abstract}
Nowicka-Franczak Magdalena, Postfoucaultowska analiza dyskursu o edukacji. Uwagi warsztatowe [Postfoucauldian analysis of the discourse on education. Workshop remarks]. Kultura - Społeczeństwo - Edukacja nr 2(12) 2017, Poznań 2017, pp. 197-223, Adam Mickiewicz University Press. ISSN 2300-0422. DOI 10.14746/kse.2017.12.10.
\end{abstract}

Postfoucauldian discourse analysis is a vigorously developing approach to discourse studies focusing on the analysis of power, discourse, knowledge and social practice. This comprises studies deriving from Michel Foucault's thought, reinterpreting it, however, with the aim at application to an analysis of empirical data, also from the field of pedagogy and education. The purpose of this paper is to present main concepts and categories of postfoucauldian discourse analysis (e.g. enunciation, discursive formation, discursive practice, procedures for the control of discourse, dispositive, regime of truth) and guidelines for conducting research on the example of an analysis of chosen public texts concerning the debate on liquidation of middle schools in Poland as a result of the reform of education carried out by Law and Justice' government.

Odnośnik do prac Michela Foucaulta znajduje się w niemal każdym opracowaniu metodologicznym analizy dyskursu, a wiele $\mathrm{z}$ tych prezentacji można by nazwać przypisem do koncepcji Foucaulta. Rozległość recepcji i wykorzystania propozycji

* Niniejszy artykuł jest owocem warsztatu metodologicznego, który odbył się podczas seminarium Dyskurs edukacyjny w ujęciu interdyscyplinarnym. Warsztaty Analizy Dyskursu w Bydgoszczy w listopadzie 2016 roku. Autorka dziękuje uczestnikom warsztatów za ich uwagi i pytania. 
metodologicznych tego myśliciela może zaskakiwać, jeśli pamięta się o tym, że właściwie nigdy nie analizował on - w sposób systematyczny i spełniający purystyczne kryteria naukowej weryfikowalności - tekstów kultury, wypowiedzi ustnych czy przekazów medialnych. Jednak sprowadzenie jego prac do teoretyzowania dyskursu byłoby nieuprawnioną redukcją. Z rozpraw i wykładów tego autora wyłania się bowiem perspektywa analityki dyskursu, związana z postulatem określonej wrażliwości krytycznej badacza i polemiczna wobec tradycji badań strukturalistycznych, hermeneutycznych oraz interakcjonistycznych. Ponadto Foucault nie stronił od czynienia wypowiedzi tekstowych, jak wyimki z traktatów naukowych, pism administracyjnych czy rozporządzeń organów władzy, ilustracją empiryczną swoich rozważań albo przyczynkiem do formułowania generalizujących ujęć społecznych relacji władzy.

Foucault (2000: 286) niejednokrotnie podejmował kwestię metody analizy władzy oraz, warunkującego jej stosowanie, nastawienia badacza na „permanentną krytykę naszego historycznego bytu", a więc krytykę bez finalnego punktu dojścia, obierającą jako swój przedmiot także metody i pojęcia, za pomocą których ta krytyka jest formułowana. Centralnym problemem metodologicznych uwag Foucaulta jest konceptualizacja analityki władzy jako refleksji nad wyłanianiem się, (nie)ciągłością i dynamiką modelu strategicznego władzy, gdzie „uprzywilejowanie prawa zastępuje się widzeniem celu, uprzywilejowanie zakazu widzeniem taktycznej skuteczności, uprzywilejowanie władzy suwerena analizą wieloaspektowego i ruchomego pola stosunków siły, gdzie wytwarzają się globalne, lecz nigdy całkowicie trwałe stosunki dominacji” (Foucault, 1995: 92). Badanie dyskursu byłoby nieodłącznym, choć niejedynym (zob. niżej) elementem analityki władzy.

Drogowskaz ten nie jest jednak wystarczającą wskazówką, jak tę metodę bezpośrednio stosować w badaniach empirycznych. Swoista kompletność i samoreferencyjność tej optyki zdaje się uniemożliwiać jej wtórne wykorzystanie w aktualnych kontekstach społecznych. Wraz z pierwszymi postfoucaltowskimi analizami dyskursu rozpoczęła się dyskusja nad możliwościami i ograniczeniami operacjonalizacji pojęć Foucaulta do analiz, po pierwsze, względnie systematycznie próbkowanych materiałów empirycznych; po drugie, do badań innych wycinków rzeczywistości niż te, $\mathrm{z}$ których pojęcia te się wyłoniły. Warto wspomnieć przegląd polemicznych wobec siebie głosów opublikowany w tomie Das Wuchern der Diskurse. Perspektiven der Diskursanalyse Foucaults pod redakcją Hannelore Bublitz, Andrei D. Bührmann, Christine Hanke, Andrei Seier (1998) i w zeszycie tematycznym Forum Qualitative Sozialforschung: From Michel Foucault's Theory of Discourse to Empirical Discourse Research (2007), redagowanym przez Andreę D. Bührmann, 
Rainera Diaz-Bone, Encarnación Gutiérrez Rodriguez, Gavina Kendalla, Wernera Schneidera i Francisca Tirado.

Chcąc w telegraficznym skrócie podsumować toczoną od przeszło trzech dekad dyskusję, można syntetycznie wyróżnić trzy głosy. Pierwszy wiąże się z akcentowaniem narzędziowości i prakseologicznego zorientowania koncepcji Foucaulta, a w konsekwencji z postulowaniem wykorzystywania pojęć i kategorii z jego prac jako specyficznej matrycy do badań empirycznych, która każdorazowo jest konkretyzowana przez badacza w odniesieniu do stawianego problemu empirycznego (Bührmann, Schneider, 2007). Charakterystyczne dla drugiego głosu jest podkreślanie, że propozycja Foucaulta nie stanowi metody w ścisłym znaczeniu, nie może zostać standardowo i sekwencyjnie opisana, ale mimo to odgrywa rolę metody w jej metawarsztatowym sensie - dotyczącym tego, czym metoda krytycznej analizy być powinna - jest więc „raczej teoretycznym, być może nawet filozoficznym nastawieniem” do prowadzenia badań (Sarasin, 2003: 8). Trzeci głos jest najbardziej sceptyczny tak wobec operacjonalizacji Foucaultowskich pojęć, jak i traktowania tego podejścia jako metody badań empirycznych. W świetle tego stanowiska ten wpływowy myśliciel uprawiał osobną i historycznie ulokowaną krytykę władzy, która nie spełnia warunków klasycznej metody badawczej - nie można tak prowadzonej analizy władzy powtórzyć, sfalsyfikować ani testować za pomocą innych materiałów i kontekstów empirycznych badań społecznych, zwłaszcza zasadniczo odbiegających od źródłowego obszaru, obejmującego między innymi chorobę psychiczną, dyscyplinowanie ciał, rządzenie populacją czy seksualność. Próby łączenia optyki Foucaulta z metodami badań jakościowych także budzą opór, ponieważ charakterystyczne dla jego postawy krytycznej było kwestionowanie szeregu kluczowych pojęć dla nauk humanistycznych i społecznych (jak na przykład postawy, działania, interakcje), a zestawianie jego podejścia z tymi, które odrzucił, prowadziłoby do zatracenia sensu i wywrotowego wymiaru jego perspektywy (Gehring, 2009; zob. także Klemm, Glasze, 2005).

Przedstawione w niniejszym artykule propozycje i uwagi odsyłają do pierwszego stanowiska, dopuszczającego operacjonalizację pojęć Foucaulta na nowych polach. Prezentowane ujęcie mieści się w szerokim obszarze analiz postfoucaultowskich, czyli takich, które zmieniają, przeformułowują i uzupełniają teoretyczny wywód filozofa z uwagi na cel, jakim jest aplikacja do badań empirycznych. $\mathrm{Z}$ tego powodu tę perspektywę badawczą określa się raczej jako postfoucaultowską niż Foucaultowską. Nieuzasadnione byłoby jednak sprowadzenie wykorzystania w tych analizach jego dorobku do roli ogólnikowej inspiracji.

W pierwszej części artykułu zasygnalizowane są wątki myśli Foucaulta, które wiążą się z zagadnieniami pedagogicznymi, oraz kierunki współczesnego wyko- 
rzystania tych rozważań w badaniach pedagogicznych. Druga część to przegląd głównych założeń i pojęć postfoucaultowskiej analizy dyskursu mogących znaleźć zastosowanie w badaniach przekazów edukacyjnych i o edukacji. W trzeciej części tekstu prezentowana jest przykładowa analiza wybranych materiałów empirycznych z dyskursu publicznego w Polsce dotyczącego sporu o likwidację gimnazjów w ramach reformy autorstwa rządu Prawa i Sprawiedliwości. Natomiast podsumowanie zbiera zalety i wady postfoucaultowskiej analizy dyskursu - zwłaszcza w odniesieniu do obszaru badań nad edukacją.

\section{Foucault a pedagogika}

Ważność prac Foucaulta dla pedagogiki jako dyscypliny naukowej z jednej strony, a z drugiej istotność problematyki pedagogicznej w myśli tego autora są akcentowane nie od dziś. Jak podkreśla Helena Ostrowicka (2015: 173), i nie jest w tym odosobniona, „[p]roblemy relacji władza - wiedza - podmiot, wyznaczające główne osie łączące prace filozofa, są centralnymi kategoriami myślenia pedagogicznego", podobnie jak wspólny dla perspektywy francuskiego filozofa i wielu współczesnych pedagogów jest krytyczny namysł nad fenomenem dyscypliny czy technik rządzenia jaźnią. Przedmiotem sporu pozostaje jednak postrzeganie głębokości Foucaultowskiej krytyki wiedzy pedagogicznej. Czy celem rozważań Foucaulta, tak jak w pedagogice krytycznej, jest opis praktyk edukacyjnych i wskazanie na ich historyczne uwikłanie w społeczne mechanizmy sprawowania władzy nad jednostkami i zbiorowością? Czy krytyka Foucaultowska idzie dalej i może kwestionować „podstawy perspektywy pedagogicznej jako dyscypliny naukowej i jako profesji, niezależnie od tego, czy mamy na uwadze tradycyjne nurty pedagogiki, zakładające raczej jednokierunkowość oddziaływania wychowawczego, czy też nurty interakcjonistyczno-dialogowe, postulujące możliwie symetryczne relacje między wychowankiem i wychowawcą" - ponieważ łączy te nurty postulat ukształtowania $\mathrm{i} /$ lub upodmiotowienia jednostki w relacji pedagogicznej lub poprzez nią (Czyżewski, 2013a: 83; 2013b: 45-48)? Podmiot zaś stanowi u Foucaulta, i części jego kontynuatorów, obiekt bodaj najdobitniejszej krytyki jako rezultat ujarzmiania (fr. assujettissement) i wytwór władzy, którego zdolność do stawiania jej oporu także uwarunkowana jest charakterem kształtujących jednostkę mechanizmów władzy ${ }^{1}$.

\footnotetext{
${ }^{1}$ W tekście Podmiot i władza Foucault (1998: 178) wymienia dwa sensy pojęcia podmiotu (fr. sujet): „zgodnie z pierwszym podmiot jest »poddany« komuś innemu za sprawą odpowiednich metod uzależnienia i kontroli, zgodnie z drugim - przykuty do swej tożsamości przez własne sumienie bądź samowiedzę. Obydwa wskazują na formę władzy, która ujarzmia i czyni poddanym". Kwestia ta
} 
Do odpowiedzi na pytanie o status tematyki pedagogicznej w myśli Foucaulta może przybliżyć namysł nad kreśloną przez niego symbiotyczną relacją władzy i wiedzy. Władza, impersonalna, rozproszona i rozumiana w tym ujęciu jako jednoczesne podglebie oraz rezultat stosunków mikro- i makrospołecznych, produkuje sytuacje dominacji, nierówności i wykluczenia dzięki wzmocnieniu i uprawomocnieniu poprzez społeczny autorytet wiedzy (zwłaszcza naukowej). Ta nie tylko opisuje, ale przede wszystkim uzasadnia i naturalizuje mechanizmy ujarzmiania jednostek i czynienia z nich podmiotów zdatnych lub niezdatnych w odniesieniu do aktualnego kształtu ładu społecznego. Wiedza (czy raczej władza-wiedza) aktualizuje się w dyskursie regionalnie i relacyjnie, a nie tyle przez wzgląd na samą jej zawartość. Regionalność wiedzy odsyła do dynamicznego charakteru legitymizacji wiedzy, która dominuje nieabsolutnie, lecz w danym regionie dyskursu czy polu władzy. Natomiast relacyjność wiedzy oznacza, że jest wytwarzana i legitymizowana zawsze w polu jakiejś sieci połączeń między instytucjami (w tym edukacyjnymi) i praktykami społecznymi, za pomocą których daną wiedzę stosuje się i implementuje w ściśle określonym kontekście (zob. Foucault, 1980: 69-70; Ristić, Marinković, 2016: 31).

Podobnie jak wyłonienie się socjologii w XIX wieku (początkowo we francusko-niemieckim obszarze kulturowym) można w ujęciu genealogicznym (zob. niżej) wiązać z oświeceniową wolą wiedzy oraz ekspansją władzy dyscyplinarnej nad populacją, która abstrakcyjny koncept społeczeństwa uczyniła widzialnym, mierzalnym i dającym się badać (zob. Ristić, Marinković, 2016) - tak i genezę pedagogiki można po Foucaultowsku wywodzić z oświeceniowego projektu kształtowania samodzielnego człowieka i obywatela, a następnie wiązać z nowoczesnymi, w tym pozytywistycznymi, strategiami normalizowania zachowań społecznych, także implementowanymi w sposób niedyrektywny, a obudowany w retorykę emancypacji. Właśnie kategoria rządomyślności (fr. gouvernementalité ${ }^{2}$ zob. Foucault, 2010; 2011) - nowoczesnej formy rządzenia populacją i jednostkami za pomocą niedyrektywnych technik, opartych na wywodzonej z chrześcijaństwa władzy pastoralnej (autorytecie duchowego przewodnictwa w samodoskonaleniu jednostki) - stała się ramą analiz współczesnego myślenia pedagogicznego i jego prefiguracji (Simons, Masschelein, 2008: 391-396), mimo wątpliwości związanych ze statusem Foucaultowskich analiz

jest rozwijana w odniesieniu do podmiotowych aktów głoszenia prawdy w cyklu wykładów Rządzenie żywmi (zob. zwłaszcza Foucault, 2014: 99-101).

2 Problem tłumaczenia na język polski pojęć rządomyślności i dyspozytywu podejmuję w innym tekście (Nowicka, 2011). 
rządzenia. Jak zauważa Nikolas Rose (1999: 19), są one „empiryczne, ale nie realistyczne", nie dotyczą faktów społecznych, organizacji i procesów będących zasadniczym przedmiotem nauk społecznych, ale raczej warunków możliwości rządzenia. Dlatego, twierdzi Rose (ibidem), rola tych analiz „jest raczej diagnostyczna niż opisowa".

Najpełniejszy wgląd w krytykę procesów edukacji i wychowania dają ostatnie cykle wykładów Foucaulta w Collège de France, z lat 1980-1984 (kursy Rządzenie żywymi, Subjectivité et Vérité, Hermeneutyka podmiotu, Le gouvernement de soi et des autres część I i II), poświęcone starożytnej sztuce życia, kierowania własnym i cudzym postępowaniem. Już w dialogach sokratejskich Foucault odnajduje impuls do krytyki pedagogii i wychowania. Odróżnia edukację w sensie ścisłym (łac. educare), czyli „przekazywanie wiedzy bądź praktycznych umiejętności”, od działania wychowawczego (łac. educere) polegającego na wyprowadzeniu jednostki z jednego sposobu bycia ku nowemu, bardziej pożądanemu w optyce tego, kto wychowuje (zob. Foucault, 2012: 140-141). Wreszcie, celem troski o siebie, którą filozof wywodzi ze starożytnej maksymy epimeleia heautou i która prowadzi go do przesunięcia akcentu $\mathrm{z}$ analityki władzy nad populacją ku analityce stosunku jednostki do samej siebie i do innych, byłoby stopniowe uwolnienie się od kurateli nauczycieli i przewodników moralno-intelektualnych - i pełne zwrócenie się jednostki ku samej sobie bez potrzeby (a może raczej pokusy?) bycia prowadzoną przez wychowawców, reprezentujących zewnętrzne mechanizmy oddziaływania na jaźń (Fisch, 2011: 380-383).

Foucault nakreśla subtelną, lecz znaczącą różnicę między zaleceniem troski o siebie a instytucjonalnymi i nieinstytucjonalnymi praktykami kierowania postępowaniem i sumieniem. Ta pierwsza oznacza postawę wobec siebie, innych i świata polegającą na skierowaniu etycznej (a więc nienarcystycznej) uważności jednostki na samą siebie poprzez konsekwentne praktyki duchowe, czego zwieńczeniem może być wgląd w prawdę o samym sobie, niedostępną dla podmiotu jako takiego, ale mogącego do niej dążyć jako do źródła transcendentnego spełnienia czy wręcz zbawienia (Foucault, 2012: 25-40). W czasach rzymskich dochodzi do rozdziału troski o siebie i pedagogii, a ta pierwsza staje się tożsama z projektem praktykowanej przez całe życie sztuki własnej egzystencji, niezależnej od nakazów wychowawczych, kontroli społecznej i polityki (Foucault, 2012: 207-208). Troska o siebie wiąże się więc ze świadomymi (a więc i etycznymi) praktykami wolności, cedowaniem na samego siebie pełni władzy nad własną jaźnią i troską o innych. Takie ujęcie praktykowania wolności wyjaskrawia jednak jego elitarny charakter, stojący w kontrze do religijnego wezwania kierowanego do wszystkich, aby zatroszczyli się w swoje zbawienie. 
W epoce ekspansji chrześcijaństwa w Europie praktyki troski o siebie, twierdzi Foucault (2013:212), „,zostają osaczone przez instytucje religijne, pedagogiczne czy medyczne i psychiatryczne". Przekształcają się w praktyki kierowania jednostkami, ich sumieniem oraz (w optyce chrześcijańskiej) duszami. Warunkiem koniecznym kierowania jest dobrowolne podporządkowanie własnej woli innemu - przewodnikowi, duszpasterzowi, mentorowi etc. Zamiast przymusu pobierania edukacji chodzi o subtelne formy cesji indywidualnej suwerenności, których zadaniem staje się ustanowienie relacji z samym sobą pozostającej w zależności od celów władzy politycznej. Relacja ta opiera się na uwewnętrznionym posłuszeństwie, kierującym postępowaniem jednostki także wtedy, gdy żadna zewnętrzna instancja nie wydaje poleceń i nie nadzoruje stosowania się do nich (Foucault, 2014: 231-235, 274-275). Do kierowania sobą potrzebna jest jednak umiejętność badania samego siebie i samooceny, której trzeba się nauczyć - i tu kluczową rolę odgrywa wpierw chrześcijańskie duszpasterstwo, a następnie sekularna pedagogia. Jej prefigurację Foucault (2008: 217, 325) odnajduje w starogreckiej psychagogii, praktykowaniu filozofii poprzez stosunek do siebie i innych. Od filozofii różni pedagogię to, że jej warunkiem jest istnienie odbiorców, którzy chcą lub muszą słuchać jej zaleceń. Doświadczanie filozofii wiąże się z jej kontestacją, pedagogia z przełamywaniem oporu. Dzięki jej praktykom jednostka może produkować samowiedzę - nie odkrywać, a wytwarzać prawdę o sobie, czyli „ujmować samego siebie w dyskurs”. Dla Foucaulta (2014: 305) upodmiotowienie łączy się z „koniecznym powiązaniem unicestwiania samego siebie i produkcji prawdy o sobie samym”, czyli de facto odrzuceniem intymnego stosunku do siebie na rzecz postrzegania jaźni w kategoriach dyskursywnych.

Słabością transponowania rozważań Foucaulta o relacjach władzy, prawdy i kondycji podmiotu do badań nad empirycznymi praktykami społecznymi jest zarówno niemożność ich metodycznej weryfikacji (zob. Gehring, 2012), jak i historyczna relacyjność oraz regionalność omawianej koncepcji, co sprawia, że jej proste przenoszenie w nowe konteksty (jak rola współczesnych dyskursów edukacyjnych i wychowawczych) może być nieuprawnione (por. Elden, 2016). Pytanie o miejsce wiedzy pedagogicznej, także tej silnie krytycznej wobec praktyk upodmiotawiających, pozostaje jednak aktualne. Akceptowalną propozycją dla badaczy zainteresowanych krytyką (post)Foucaultowską, ale dalekich od odrzucania tożsamości pedagogiki jako pozytywnej wiedzy i praktyki samostanowienia, być może byłby postulat minimalnej, lecz konsekwentnej krytyki koniecznego uwikłania edukacji i wychowania w relacje władzy. Sam Foucault (2013: 236) w jednym z ostatnich wywiadów odcina się od radykalnych sądów o pedagogicznej władzy i w prostych słowach kreśli plan minimalnej krytyki: 
Nie widzę żadnego zła w praktyce kogoś, kto w danej grze prawdy, wiedząc więcej od drugiego, mówi mu, co należy robić, uczy go, przekazuje mu wiedzę, informuje o technikach; problem polega raczej na tym, jak unikać w tych praktykach - gdzie władza musi się uobecniać i gdzie nie jest zła sama w sobie - skutków dominacji [nad jaźnią - przyp. aut.], która sprawia, że dzieciak jest podporządkowany arbitralnemu i bezużytecznemu autorytetowi nauczyciela, student jest zależny od autorytarnego profesora.

Postfoucaultowska analiza edukacji i wychowania ma znaczący dorobek badawczy. Ogólną metodologiczną refleksję nad możliwościami zastosowania Foucaultowskiej optyki w empirycznych badaniach dyskursu zainicjowano w latach 80. XX wieku, natomiast dekadę później zaczęły się ukazywać pierwsze podręczniki inspirowanych perspektywą francuskiego filozofa metod badawczych albo przynajmniej obejmujące rozdziały poświęcone analizie dyskursu à la Foucault (zob. Nowicka-Franczak, 2017a). W ostatnim dziesięcioleciu minionego stulecia do rąk badaczy trafily prace bezpośrednio odnoszące pojęcia i kategorie tego myśliciela do pedagogiki. Spośród prekursorskich spojrzeń na wyróżnienie zasługują ówczesne próby genealogii wiedzy pedagogicznej i instytucji edukacyjnych (między innymi Hunter, 1994; Marshall, 1996), a także prowadzenia Foucaultowskiej $\mathrm{w}$ duchu analityki władzy regulującej pole edukacji i wychowania (początkowo koncentrowano się na władzy dyscyplinarnej, między innymi Pongratz, 1989; Ball, 1992). Niedługo później pojawiły się opracowania metodologiczne, których celem była operacjonalizacja perspektywy Foucaulta do badań współczesnych zagadnień pedagogicznych (między innymi Pongratz, 2004), oraz zbiory nowych odczytań klasycznych tekstów tego autora przez pryzmat wskazanej tematyki (na przykład Ricken, Rieger-Ladich, 2004).

Z uwagi na ograniczoną objętość tego artykułu nie ma tu miejsca na drobiazgową rekonstrukcję dorobku analiz postfoucaultowskich w obszarze badań nad edukacją i wychowaniem. Bogata bibliografia opracowań w języku polskim, angielskim i niemieckim znajduje się w pracy Heleny Ostrowickiej pt. Przemyśleć $z$ Michelem Foucaultem edukacyjne dyskursy o młodzieży (2015). Podobnie jak w postfoucaultowskiej analizie dyskursu jako takiej, również w odniesieniu do pedagogiki więcej badań prowadzonych jest dziś w krajach anglo- i niemieckojęzycznych niż w ojczyźnie Foucaulta, ale i tam ukazują się cenne poznawczo publikacje (na przykład Audureau, 2003; Donzelot, Gordon, 2005). Także w polskiej pedagogice recepcja oraz wykorzystanie pojęć Foucaultowskich i postfoucaultowskiej perspektywy metodologicznej zatacza coraz szersze kręgi. Wśród autorów, którzy przyczynili się do wprowadzenia tej optyki w akademicki obieg, należy wymienić między innymi (w kolejności alfabetycznej): Maksymiliana Chutorańskiego (2013), Agnieszkę Gromkowską-Melosik (2004), Dorotę Klus-Stańską (2015), 
Zbyszko Melosika (2009; 2013), Marię Mendel (2007), Astrid Męczkowską-Christiansen (2006), Helenę Ostrowicką (2012; 2015). Ich prace stanowią nie tylko ilustrację szerokiego przekroju problemowego odniesień Foucaultowskich w polskiej pedagogice (od badań praktyk i dyskursów instytucjonalnych na różnych etapach obowiązkowej edukacji szkolnej przez problematykę konstruowania tożsamości płciowych i kulturowych w dyskursach edukacyjnych, w tym medialnych, analizy normalizowania życia jednostek poprzez mechanizmy biopolityczne i sekurytyzacyjne, których nośnikami są dyskursy neoliberalne, w tym dyskurs nauki legitymizujący lub przejmowany do legitymizacji aktualnej formy rządzenia społeczeństwem, po refleksję nad możliwymi strategiami oporu przeciwko narzucanemu z zewnątrz kształtowi podmiotowości). Różnią się także rolą, jaką odgrywają w tych pracach pojęcia zaczerpnięte od Foucaulta i badaczy postfoucaultowskich - i układają się na kontinuum od zasadniczo teoretycznego po stricte analityczne zastosowanie tego instrumentarium (zob. Simons, Masschelein, 2006: 421-422).

W ramach badań postfoucaultowskich silnie rozwinięta jest metarefleksja nad recepcją dzieł Foucaulta oraz stopniem adaptacji jego optyki do analiz empirycznych. W stosunku do pedagogiki w Polsce spojrzenie porządkujące tryby użytku $\mathrm{z}$ prac tego filozofa $\mathrm{w}$ badaniach empirycznych i w podręcznikach akademickich można znaleźć zwłaszcza w monografiach Chutorańskiego (2013) i Ostrowickiej (2015). Nie chcąc powtarzać ich wniosków, skupię się na jednym aspekcie metodologicznym postfoucaultowskich badań pedagogicznych. Są one, podobnie jak analizy socjologiczne czy politologiczne, zależne od fal „mody na Foucaulta”. Po pierwsze, eksplorują za pomocą metod hermeneutycznych pojemne pojęcia, jak władza dyscyplinarna, heterotopie, archiwum czy po prostu dyskurs, bez konsekwentnego stosowania Foucaultowskich podejść metodologicznych, jak archeologia i genealogia. Po drugie, wpisują się w prężny nurt studiów nad neoliberalną rządomyślnością, którego znaczącymi przedstawicielami w polu badań nad edukacją byli (obecnie zmienili punkt ciężkości swoich zainteresowań) Maarten Simons i Jan Masschelein, autorzy tyleż płodni, co powtarzalni w diagnozach neoliberalnej ekspansji praktyk edukacyjnych wprzęgniętych w wytwarzanie nowego typu podmiotu: „przedsiębiorcy samego siebie”. Wreszcie, rozwija się analiza dyspozytywu. Jej sednem, mówiąc najzwięźlej, jest holistyczna analiza jakościowa dyskursywnych i niedyskursywnych praktyk, które regulują interesujący badacza wymiar rzeczywistości społecznej i zarazem stanowią składnik szerszej siatki relacji władzy, dającej się badać empirycznie w ograniczony sposób (Nowicka, 2016). Analiza dyspozytywu sięga do kategorii Foucaulta (głównie z późnego okresu) i do metody analizy dyskursu (Ostrowicka. 2012; Othmer, Weich, 2015). W polu edukacji i wychowania stosunkowo rzadko prowadzone są natomiast samodzielne 
postfoucaultowskie analizy dyskursu, zwłaszcza mikroanalizy tekstów. Foucault mikroanaliz nie podejmował, ale zasadą postfoucaultowskiej analizy dyskursu jako takiej są właśnie próby przekroczenia oryginalnej perspektywy w kierunku nowych zastosowań, nie unikając jej modyfikacji, lecz zachowując wektor Foucaultowskiej krytyki władzy. Celem kolejnych części artykułu jest zachęta do podejmowania takich prób.

\section{Główne założenia i pojęcia postfoucaultowskiej analizy dyskursu}

Najistotniejsze założenia postfoucaultowskiej analizy dyskursu można wyabstrahować z samej koncepcji dyskursu u Foucaulta. Ta ewoluowała na przestrzeni lat i stopniowo dyskurs z centralnej kategorii, jaką był w pracach z lat 1961-1970, stał się kategorią pomocniczą - wciąż ważną, lecz stanowiącą raczej analityczne zaplecze dla wysuwającej się na pierwszy plan tematyki technik rządzenia populacją, wytwarzania podmiotów oraz relacji prawdy i władzy. Niezmienne pozostało jednak ujmowanie dyskursu jako nośnika dynamicznych relacji społecznej władzy i nierozerwalnie związanej z nią wiedzy (władzy-wiedzy). Foucault odrzuca dychotomiczny podział na dominujący dyskurs władzy i dyskurs przez nią zdominowany, a podkreśla konstytutywną dla dyskursu jako takiego rolę gry znaczeń, której granice wyznaczają relacje władzy. Pojmuje dyskurs jako „pole strategiczne, którego elementy, taktyki, broń nie przestają przechodzić z jednego obozu do drugiego i zmieniać się między adwersarzami, i zwracać się przeciwko tym samym, którzy je stosują" (Foucault, 2001 [1976]: 123). Dyskurs to rodzaj (prze)mocy, środka „władzy, kontroli, ujarzmienia, kwalifikacji i dyskwalifikacji”, ściśle splecione jest z nim również to, co niewypowiedziane, co zamanifestowane w sposobie bycia, w stosunkach społecznych (ibidem). W świetle tej koncepcji dyskurs jest rzadkim, nieciągłym fenomenem, który ściśle filtruje doświadczenie i ocenę rzeczywistości społecznej, wykluczając lub marginalizując wiele możliwych, alternatywnych spojrzeń.

Co tak szeroko zakrojona wizja dyskursu oznacza w perspektywie analitycznej? Przede wszystkim wiąże się z postulatem krytycznej rekonstrukcji porządku dyskursu, sposobu regulacji wytwarzania wypowiedzi wchodzących w skład dyskursu, ich selekcji, kontroli, organizacji i dystrybucji (Foucault, 2002: 7). Z kolei wypowiedź - podstawowa jednostka analizy w postfoucaultowskich badaniach dyskursu - nie jest tu rozumiana ani jako struktura gramatyczna, ani konwencjonalny akt mowy, ani miara tekstu. Można ją porównać do fragmentu dyskursu, funkcjonalnej całostki, przywołującej pewną wiedzę i sposoby klasyfikacji opisy- 
wanego wycinka rzeczywistości oraz implikującej określoną pozycję podmiotu mówiącego wobec przedmiotu wypowiedzi. W praktyce badawczej materialną formą wypowiedzi jest najczęściej tekst lub jego fragment (na przykład zdanie, akapit, paragraf aktu prawa), graficzne zestawienie danych statystycznych, slogan z towarzyszącym mu obrazem. Co ważne, te drobne realizacje dyskursu mają przypisaną funkcję wypowiedzeniową: służą między innymi diagnozie, argumentacji, orzekaniu (zob. Bacchi, Bonham, 2014).

W ramach postfoucaultowskiej analizy dyskursu metodologiczne „obchodzenie się” z wypowiedziami może przybrać różny kształt. Wybierając ścieżkę wczesnych prac Foucaulta, gdzie ten eksploruje podejście zwane przez niego archeologicznym, badacz podąża traktem analizy socjolingwistycznej oraz refleksji nad historycznością dyskursu i reguł jego formowania. Celem archeologii jest opis archiwum - za tym pojęciem kryje się nie tyle kolekcja wypowiedzi zaistniałych w określonym kontekście czasowym, kulturowym i społecznym, co rezerwuar reguł wyznaczających w danej epoce i regionie wiedzy zakres tego, co może zostać wypowiedziane i może stać się częścią prawomocnego dyskursu. Perspektywa archeologiczna daje pośredni wgląd w porządek wiedzy o świecie społecznym, który to porządek wytwarza, petryfikuje, ale i zmienia społeczne hierarchie oraz układ sił między jednostkami i zbiorowościami. Funkcja porządku wiedzy, którego oprzyrządowaniem jest porządek dyskursu, wydaje się zasadniczo zbieżna z zasadą oddziaływania pedagogicznego tak wobec indywiduum, jak i w kontekście podtrzymywania ładu społecznego.

W Archeologii wiedzy pojawia się często cytowane, ale sprawiające wiele kłopotów w interpretacji stwierdzenie, iż dyskurs to „zbiór wypowiedzi należących do jednej formacji dyskursywnej” (Foucault, 1977: 150). Ten zespół jakościowych reguł kształtujących wypowiedzi i wiążących je w dyskurs obejmuje aspekt:

1) zbieżnego przedmiotu (na przykład reforma edukacji);

2) modalności - sposobu uwiarygodniania wypowiadanej formy treści, także poprzez zajmowanie przez podmiot mówiący określonej pozycji wobec tego, co mówione (na przykład eksperckie odwołania do wiedzy naukowej, kwalifikowanej lub rodzicielska mobilizacja emocji i wiedzy płynącej z codziennego doświadczenia);

3) koherencji pojęć i klasyfikacji występujących w wypowiedziach (na przykład odniesienia do progresu/regresu edukacyjnego, wyrównywania szans między uczniami z różnych środowisk, unowocześniania szkoły);

4) celu strategicznego, któremu podporządkowana jest wypowiedź (na przykład uzasadnienie celowości reformy edukacji, rozliczenie politycznych przeciwników albo krytyka działań rządu). 
Analiza nie zatrzymuje się na poszukiwaniu regularności w zbiorze wypowiedzi. Istotnym krokiem jest wskazywanie miejsc niezgodności, niespójności, zerwań między wypowiedziami i lokowanie ich w konstelacji społecznych dyskursów, a więc rekonstrukcja interdyskursywnych stosunków opozycji, oddzielenia, analogii czy komplementarności, unaoczniających to, co zostało z badanego dyskursu wykluczone (Koller, Lüders, 2004: 62).

Foucault dość swobodnie używał kategorii formacji dyskursywnej, tak w liczbie pojedynczej, jak i mnogiej. W analizie empirycznej ta niejednoznaczność rodzi pytanie: czy dyskurs należy utożsamiać z jedną formacją dyskursywną, czy w danym dyskursie jest miejsce dla wielu formacji? Biorąc pod uwagę szerokość samego pojęcia dyskursu u Foucaulta, przychylam się do drugiej opcji, ponieważ immanentną cechą dyskursu jest nieciągłość i zmiana generująca opór, manifestowany również w polu dyskursywnym. Ewolucja problematyki pedagogicznej także dokonuje się poprzez pojawianie się treści, pojęć i celów rozumianych opozycyjnie wobec dotychczasowych wizji tego, jak uczyć i wychowywać oraz jakie podmioty kształtować. Stąd miejsce dla więcej niż jednej formacji dyskursywnej w obrębie pozostającego w ruchu dyskursu, rozgrywającego dynamiczne relacje władzy.

Zasygnalizowana w podejściu archeologicznym problematyka przygodności dyskursu wybrzmiewa zwłaszcza w perspektywie genealogicznej i socjologiczno-historycznym nurcie badań postfoucaultowskich ${ }^{3}$. Genealogia postuluje badanie labilnych taktyk i strategii władzy, a w odniesieniu do dyskursu - praktyk dyskursywnych. Tak określa się zarówno reguły formacyjne, jak i procedury kontroli dyskursu, wewnętrzne i zewnętrzne wobec niego, jako rezultat powiązań między różnymi instancjami władzy-wiedzy. Genealogia oznacza poszerzenie horyzontu analizy o sferę praktycznego - nie tylko dyskursywnego - wytwarzania hierarchicznego oraz typizującego postrzegania i wyjaśniania rzeczywistości.

Konsekwencją próby tak rozległego spojrzenia jest silne włączenie (a w późnych i ostatnich pracach Foucaulta postawienie w centrum zainteresowania) kwestii podmiotu jako fundamentalnego wytworu mechanizmów władzy-wiedzy. Te ostatnie można uszeregować od jawnych, jaskrawych, związanych z dyscyplinowaniem ciał i nierzadko przejawiających się w formie fizycznej izolacji lub przemocy wobec jednostek (na przykład kary cielesne, tzw. ośle ławki, szkolny ostracyzm czy architektura i organizacja przestrzeni w placówkach pedagogicznych, ułatwiająca nadzorowanie podopiecznych), po te niejawne, subtelne, ale niekiedy znacznie skuteczniej przekształcające człowieka w podmiot „zatroskany o siebie” w okre-

${ }^{3}$ Ścisłe rozdzielanie perspektyw badawczych archeologii, genealogii i analizy dyspozytywu wydaje się bezprzedmiotowe. Zazwyczaj ich elementy są obecne łącznie w postfoucaultowskich badaniach empirycznych. 
ślony sposób, świadomy własnego wpływu na swój dobrostan, pozycję w społeczeństwie i dobrowolnie, w oparciu o nabytą samowiedzę, realizujący scenariusze tożsamościowe podsuwane z zewnątrz. Ważnym wątkiem u omawianego myśliciela, odnoszącym się też do postfoucaultowskich badań pedagogicznych, jest to, iż nauka, nawet autokrytyczna i wyczulona na mechanizmy władzy, dokłada poprzez krytykę stanu poprzedniego cegiełkę do galerii praktyk służących klasyfikacji podmiotów i projektowaniu ich nowego typu: mniej uprzedmiotowionego i bardziej samoświadomego. Paradoks ten nie omija postfoucaultowskich analiz dyskursu i dyspozytywu, które wręcz potrzebują oznaczania podmiotu i jego typów do uzasadnienia „doniosłości” swoich ustaleń. Prowadząc empiryczne badania dyskursu i dyspozytywu, należy jednak pamiętać, że to nie dyskurs wytwarza podmioty, lecz władza i porządek wiedzy poprzez dyskurs i związane z nim praktyki (Schneider, 2015: 28-29).

W ujęciu genealogicznym służą temu wyróżnione przez Foucaulta (2002: $7-14,27)$ procedury kontroli dyskursu. Do zewnętrznych wobec dyskursu procedur zalicza wykluczenie pewnych zdań i stanowisk. Następuje ono z uwagi na zakaz wypowiadania określonych treści: bez względu na okoliczności albo w wybranych kontekstach sytuacyjnych czy poprzez udzielanie przywileju mówienia tylko szczególnym typom podmiotów. Wykluczeniu sprzyja kreślenie opozycji rozumu i szaleństwa, a na jej mocy odrzucanie treści uznanych za irracjonalne, oraz opozycji prawdy i fałszu, podbudowanego autorytetem wiedzy naukowej klasyfikowania treści jako prawdziwe/fałszywe. Procedury te mają wymiar historyczny i dopiero analiza długich okresów lub analiza porównawcza pozwala rozstrzygnąć o zakresie i formie wykluczenia.

Do wewnętrznych procedur kontroli dyskursu należy komentarz, zasada autora i organizacja dyscyplin. Zadaniem komentarza jest takie „powtórzenie” lub „dopowiedzenie" pierwotnej wypowiedzi, które zmienia jej sens lub ma ukierunkowywać jej strategiczne odczytanie. Mianem zasady autora określa się strategię wydzielania zbioru wypowiedzi na podstawie przypisania ich do określonego autora - nie tyle osoby, co funkcji dyskursu służącej „stemplowaniu” wypowiedzi jako rzekomo jednorodnych, spójnych (pod kątem sensu, modalności lub strategicznego celu) i pozwalających się zaklasyfikować z uwagi na figurę ich autora. Organizacja dyscyplin dotyczy z kolei regulacji sposobów formułowania wypowiedzi, tak aby mogły zostać zaszeregowane do specyficznego obszaru wiedzy i uznane za prawomocny przekaz. Ponadto Foucault wspomina procedurę rozrzedzenia podmiotów mówiących poprzez stawianie im warunków dotyczących na przykład ich wiedzy, kwalifikacji oraz kontekstu, w jakim dane podmioty miałyby pełnić funkcję autorów prawomocnych treści. 
Tym niemniej to analiza materialności dyskursu daje wgląd, choć niebezpośredni, w porządek wiedzy i mechanizmy społecznej władzy. Nie należy stawiać znaku równości między postfoucaultowską analizą dyskursu a rekonstrukcją struktur tekstów. Rekonstrukcja porządku dyskursu nie stanowi też finalnego celu analizy, a daje podstawy do wnioskowania abdukcyjnego o niedyskursywnej siatce relacji władzy, rzutującej na dyskursywizowane w wypowiedziach opisy rzeczywistości, problematyzacje zjawisk społecznych, klasyfikacje i projekty podmiotów indywidualnych lub zbiorowych. Nadrzędnym zadaniem, możliwym do realizacji w ograniczonym stopniu, jest opis reżimów prawdy, nieuświadomionych dla jednostki zasobów i granic prawomocnego rozumienia świata. Reżimy prawdy to „rodzaj[e] relacji wiążących akty ujawniania prawdy i właściwe im procedury z podmiotami dokonującymi owych aktów lub będącymi ich świadkami bądź przedmiotami” (Foucault, 2014: 117). Socjolog czy pedagog próbujący uchwycić aktualny kształt reżimu prawdy wpada nieuchronnie w jego pułapkę, gdyż działanie badacza polega właśnie na proponowaniu prawomocnej diagnozy rzeczywistości w jakimś obszarze kultury i życia społecznego (por. Audureau, 2003: 26), w tym przypadku diagnozy „kierowanej” pojęciami Foucaulta.

Podsumowując: w postfoucaultowskiej analizie dyskursu stawiane są następujące pytania badawcze: Jaka prawda, w jaki sposób wytwarzana, opisuje dany obszar rzeczywistości? Jakie pojęcia, modalności i strategie argumentacyjne są wykorzystywane do tego? Jaka wiedza reguluje badany problem, jaka płynie z proponowanych rozwiązań? Jaki podmiot ma być efektem zmiany, jaki jest podmiot mówiący o tej zmianie? Co zostało wykluczone z dyskursu, unieważnione, zmarginalizowane lub całkowicie pozbawione głosu?

\section{Dyskurs o edukacji - przypadek sporu o gimnazja}

Przedmiotem przeglądowej i ilustracyjnej analizy jest spór o zasadność likwidacji gimnazjów i powrotu do ustroju edukacji powszechnej, który obejmuje osiem klas szkoły podstawowej, cztery klasy liceum ogólnokształcącego, pięć klas technikum i dwa do trzech lat nauki w innych typach szkół ponadpodstawowych. Wprowadzenie reformy wiąże się z koniecznością opracowania nowej siatki szkół w Polsce, likwidacją lub wygaszaniem gimnazjów i obawami o redukcję etatów nauczycieli uczących w tym typie szkół. Wielu komentatorów podkreśla tempo wprowadzania zmian - ustawa Prawo oświatowe z 14 grudnia 2016 roku, opublikowana w Dzienniku Ustaw 11 stycznia 2017 roku zmieniła organizację nauki w szkołach już od września 2017 roku. Kwestia gimnazjów to tylko jeden aspekt wcielanej przez rząd 
Prawa i Sprawiedliwości reformy i niejedyne zarzewie konfliktu między Ministerstwem Edukacji Narodowej, samorządami, dyrektorami szkół, nauczycielami, związkami zawodowymi, rodzicami i uczniami. Jednak to problem likwidacji gimnazjów ogniskuje uwagę dużej części uczestników sporu i publiczności obserwującej go w mediach. Publiczna reprezentacja sporu została skonstruowana wokół tematu gimnazjów, to przez jego pryzmat podnoszone i oceniane są inne sporne sprawy (między innymi zarobki nauczycieli czy wydatki samorządów).

Większość wypowiedzi w sporze o gimnazja, zwłaszcza te w mediach publicystycznych i społecznościowych, trudno uznać za elementy dyskursu edukacyjnego lub pedagogicznego w klasycznym sensie. Należą one do szerokiego publicznego dyskursu o edukacji. W jego polu znajdują się głosy eksperckie, przekładające język wiedzy naukowej na argumentację skierowaną do laika, enuncjacje wpisujące dyskusję o gimnazjach w spór stricte polityczny czy świadectwa oparte na własnym doświadczeniu (nauczyciela, rodzica, ucznia). Łączy je to, że dosłownie lub pośrednio stawiają problem kształtu systemu edukacji, jego społecznej odpowiedzialności za formowanie wiedzy i charakterów młodych ludzi. Dlatego warto dyskurs o edukacji analizować w perspektywie postfoucaultowskiej, gdyż dotyka centralnych dla tej analityki władzy zagadnień, jak rządzenie istotną częścią populacji (dzieci i młodzież) oraz projektowanie podmiotów „dojrzałych” do określonych zadań społecznych. Przykład dyskursu o edukacji, jakim jest spór o gimnazja, wiąże się też z dyskursywnymi i niedyskursywnymi praktykami oporu wobec zmian w systemie oświaty i publicznymi aktami prawdy o polskiej szkole formułowanymi przez uczestników konfliktu. Rdzeń sporu to pytanie o prawdę i prawomocne sposoby jej wyrażania, a jego efekt to wytworzenie wielu konkurencyjnych „prawd” osadzonych w dynamicznym porządku wiedzy.

Dla potrzeb warsztatowej analizy zebrano niewielką próbę przekazów (21), które pojawiły się w ogólnopolskich mediach lub internetowych bazach danych od września 2016 roku (publikacja projektu ustawy Prawo oświatowe) do marca 2017 roku (ogólnopolskie strajki rodziców i nauczycieli). Kryterium doboru materiałów nie było więc dążenie do zbudowania korpusu wyczerpującego pod kątem stanowisk i typów argumentacji proporcjonalnie do ich widoczności w sporze. Zastosowano kryterium formalne i podmiotowe. Celem było zebranie przykładów prezentujących różne formy i funkcje medialnego przekazu oraz odmienne pozycje podmiotu mówiącego wobec podejmowanej tematyki. W analizowanym zbiorze znalazły się: projekt ustawy, informacja kierowana do szerokiej publiczności poprzez stronę internetową MEN, wypowiedzi eksperta i nauczycielki gimnazjum dla prasy, dziennikarskie glosy, wpisy rodzica i innych osób w mediach społecznościowych, wykres z wynikami badań opinii publicznej, baner protestacyjny, uchwała i list związku 
zawodowego, fragment telewizyjnej audycji publicystycznej, fragment wywiadu radiowego $\mathrm{z}$ rodzicem, zapis obrad rady miejskiej i oficjalne stanowisko MEN wobec strajku nauczycieli. W przypadku relatywnie długich i wielowątkowych materiałów jako wypowiedzi poddane analizie potraktowano te fragmenty, które albo eksplicytnie odnosiły się do kwestii nowego ustroju oświaty, albo można było przyporządkować im określoną funkcję wypowiedzeniową - w przypadku sporu związaną zazwyczaj z zajęciem stanowiska wobec przedmiotu dyskusji i jej uczestników. Dobór wypowiedzi był więc w pewnej mierze arbitralny, podyktowany warsztatowym charakterem niniejszej analizy i koncentracją na wyrazistych przykładach.

Kwestie problemowe obejmują przedstawione w poprzedniej części artykułu ogólne pytania badawcze charakterystyczne dla postfoucaultowskiej analizy dyskursu. Dodatkowe pytania wynikają z tego, że analizie poddano wypowiedzi tekstowe powstałe w określonym kontekście czasowym, politycznym i społecznym. Pytania te dotyczą:

1) zbieżności i rozbieżności w kategoriach, pojęciach i zasobach wiedzy aktualizujących się $\mathrm{w}$ wypowiedziach reprezentujących różne stanowiska w sporze o gimnazja;

2) obserwowalnych na poziomie tekstu skutków procedur kontroli dyskursu (uwaga: w świetle tej perspektywy istotne są konsekwencje praktyk dyskursywnych, nie zaś spekulowanie o intencjach podmiotów mówiących);

3) relacji między wypowiedziami i odniesien do innych nieedukacyjnych dyskursów;

4) formy władzy nad populacją będącej podstawą produkcji tych wypowiedzi.

Poniżej znajdują się propozycje analitycznej interpretacji trzech przykładowych wypowiedzi z wykorzystaniem omawianych wyżej kategorii i pojęć.

\section{Przykład 1}

Ważnym elementem projektów ustaw jest uzasadnienie planowanej zmiany prawa. Zawiera je także projekt ustawy Prawo oświatowe z września 2016 roku. Pierwsza część służy klasyfikacji dotychczasowego systemu oświaty jako porażki - zarówno pod względem organizacji placówek, jak i realizacji celu wyrównywania szans edukacyjnych między ośrodkami wielkomiejskimi a wiejskimi; druga to opis planowanej zmiany na różnych szczeblach powszechnej edukacji. Przywoływana jest wiedza naukowa, kwalifikowana - raporty z badań PISA (Międzynarodowego Programu Oceny Umiejętności Uczniów OECD) nad kompetencjami polskich 15-latków w porównaniu z ich rówieśnikami z innych państw. Podkreśla się międzynarodowy charakter badań, co ma dodatkowo uprawomocniać ich wynik. Wnioski 
z badań PISA, wbrew obiegowej dumie z dobrych rezultatów młodych Polaków, są tu prezentowane jako dowód na to, że gimnazja nie poprawiają znacząco potencjału uczniów i pogłębiają różnice w osiągnięciach młodzieży uczęszczającej do tej samej szkoły. Ukrytą strategią uzasadnienia do projektu ustawy, choć utrzymanego w modalności profesjonalnej, biurokratycznej i bezstronnej, jest unieważnienie dyskursu poprzedniego rządu o sukcesie modernizacyjnym polskiej szkoły w budowaniu europejskiego „społeczeństwa opartego na wiedzy” poprzez wyposażenie młodzieży w odpowiedni pakiet umiejętności (zob. Ostrowicka, 2012: 194-198). Nie oznacza to, że w uzasadnieniu nie ma miejsca dla racjonalności ekonomicznej i dla gry między formacjami pojęć typowymi dla dyskursu neoliberalnego (kojarzonego z przeciwnikami politycznymi autorów ustawy) oraz dla nieliberalnego dyskursu powrotu do tradycyjnych wartości. Do zestawu pojęć i kategorii formujących znaczenie uzasadnienia należą między innymi: działalność innowacyjna (w szkołach) oraz dostosowanie kształcenia do potrzeb rynku pracy; postawy kreatywności i przedsiębiorczości czy partycypacja w osiągnięciach cywilizacyjnych społeczeństwa (u uczniów).

Przedmiotem szczegółowego namysłu jest fragment uzasadnienia z paragrafu pt. Wzmocnienie roli szkoły $w$ budowaniu kompetencji niezbędnych do funkcjonowania we współczesnym świecie, który proponuję traktować jako osobną wypowiedź, pełniącą funkcję aksjonormatywnej deklaracji ustawodawcy, odróżnienia nowej wizji edukacji od dyskursu podtrzymującego status quo i wezwania określonych podmiotów do wdrażania zmiany.

Głównym obowiązkiem szkoły, rodziny i społeczeństwa XXI wieku jest kształcenie i wychowanie młodego pokolenia w poszanowaniu wartości, odpowiedzialności, współpracy. Istotne jest zarówno kształtowanie postaw patriotycznych, obywatelskich, poczucia tożsamości i świadomości narodowej, kulturowej i indywidualnej, jak również umiejętność kreatywnego myślenia, otwartość na poszukiwanie nowych rozwiązań i umiejętność sprawnego poruszania się w zmieniającym się współczesnym świecie. Realizacja tego obowiązku wymaga partnerstwa i odpowiedzialności oraz budowania dobrych relacji między rodzicami, nauczycielami i uczniami.

Obecnie, jak wskazują pedagodzy, w znacznej mierze utracił aktualność tradycyjny model szkoły. W efekcie znacząco osłabił się autorytet szkoły, jako instytucji. W związku z powyższym zaproponowano zmiany w przepisach art. 1 ustawy Prawo oświatowe, [które - przyp. aut.] tworzą ramy do lepszego funkcjonowania szkół w dzisiejszym świecie, a tym samym do odbudowy prestiżu społecznego i autorytetu instytucji oświatowych.

Nadanie zadaniom wychowawczym realizowanym w szkołach i placówkach systemu oświaty odpowiedniej rangi wymagało zaakcentowania jego [wychowania - przyp. aut.] znaczenia przez wymienienie go wśród szczególnych zadań systemu oświaty. Takie przepisy wskazują jednocześnie na nadrzędną rolę wychowania oraz wspierającą i uzupełniającą rolę profilaktyki problemów dzieci i młodzieży. (Uzasadnienie, 2016) 
Wypowiedź rozpoczyna się od katalogu zadań szkoły w powiązaniu z obowiązkami rodziny i społeczeństwa jako całości. Zwraca uwagę kolejność wskazań, implikująca hierarchiczny porządek: w pierwszej kolejności szkoła ma kształtować postawy patriotyczne, $\mathrm{w}$ drugiej obywatelskie, w pierwszej - poczucie tożsamości narodowej i kulturowej, w drugiej - indywidualnej. Wreszcie, jej funkcją ma być stymulowanie kreatywnego myślenia, otwartości na nowe i elastyczności w dynamicznym świecie. Pojęcia formujące tę wypowiedź wydają się rezultatem cyrkulacji neoliberalnego dyskursu edukacyjnego, którego odpryski zostają przejęte przez dyskurs tradycjonalistyczny, lecz rozłożenie akcentów pozwala rozpoznać miejsca opozycji wobec tego pierwszego. Modalność wypowiedzi ma wymiar explicite postulatywny - chodzi o budowanie symetrycznych (partnerstwo) i dobrych relacji między rodzicami, nauczycielami i uczniami. Jednak sam zapowiadany akt prawny jest dyrektywny, określa i dyscyplinuje postępowanie wyżej wymienionych podmiotów. Uzasadnienie projektu ustawy stanowi apel do odpowiedzialnych podmiotów, czyli takich, które poprą i wdrożą zmianę, zaś celem stanowienia prawa jest unormowanie praktyk edukacyjnych w populacji.

$\mathrm{W}$ wypowiedzi tej znajduje się odwołanie do wiedzy naukowej, czyli „prawdziwej", ale traktowanej niczym wiedza potoczna. Jacyś pedagodzy wskazują na kryzys tradycyjnego modelu szkoły - nie wiadomo jacy, ilu, z jakiej pozycji występujący etc. Funkcją tego odwołania nie jest jednak dyskusja z różnymi typami wiedzy, ale poprzez diagnostyczno-mobilizacyjny charakter i temporalne odniesienia wiąże się ona z problematyzacją (w sensie stosowanym przez Foucaulta [1995]: historycznego wyłaniania się pewnych kwestii jako problemów, przedmiotów wypowiedzi oraz obiektów gry między kategoriami prawdy i fałszu) obniżającego się autorytetu instytucji oświatowych w społeczeństwie, który to problem trzeba rozwiązać. Środkiem naprawczym ma być nowe prawo, w dyskursywnej warstwie wysoko rangujące wychowawczą rolę szkoły (której tradycjonalistyczno-neoliberalny wektor był wskazany na początku wypowiedzi). Pytaniem dla badacza pozostaje zaś to, jakie praktyki instytucjonalne i niedyskursywne towarzyszą aktowi prawnemu, aby zmienić polską szkołę nie tylko w obszarze dyskursu na jej temat.

Analizowany przykład kończy uwaga o problemach dzieci i młodzieży. To ta grupa społeczna jest w całym uzasadnieniu ustawy zarówno głównym podmiotem zmiany (ma się kształcić na nowego Polaka i obywatela), jak i podmiotem najsilniej uprzedmiotowionym jako źródło ryzyka niepowodzenia planowanego przedsięwzięcia i obiekt prewencji (por. Ostrowicka, 2012: 177-180). Reasumując: wydaje się, że praktyki dyskursywne warunkujące tę wypowiedź włączają ją w pole rządomyślności, rozumianej jako niedyrektywna forma władzy nad po- 
pulacją. Jednak instytucjonalne i niedyskursywne konsekwencje wprowadzenia postulowanych tu zmian mogą już być przejawem władzy dyscyplinarnej i normującej.

\section{Przykład 2}

Na różnych etapach sporu o gimnazja "Gazeta Wyborcza”, dziennik o profilu liberalno-lewicowym, systematycznie publikowała teksty (wywiady, glosy dziennikarskie, informacje i opinie) podważające zasadność likwidacji gimnazjów. Wiele $\mathrm{z}$ nich jest zgodnych pod względem przedmiotu, pojęć i celu strategicznego z aktualnym dyskursem krytyki rządu Prawa i Sprawiedliwości. Do artykułowania stanowiska politycznego nierzadko jest zaprzęgnięta wiedza naukowa i podmiot mówiący z pozycji eksperta. Przykładem takiego strategicznego użycia wiedzy jest wywiad z 18.10.2016 roku Justyny Sucheckiej (dziennikarki specjalizującej się $\mathrm{w}$ tematyce edukacji) $\mathrm{z}$ dr. Maciejem Jakubowskim, ekonomistą. W nocie towarzyszącej rozmowie ujęta jest polityczna, profesjonalna i naukowa tożsamość autora: W latach 2012-14 wiceminister edukacji, przedtem $w$ zespole zarzadzajacym badaniem PISA w OECD w Paryżu. Byt konsultantem Banku Światowego, OECD, UNDP oraz rzadów w Europie i Azji. Autor kilkudziesięciu artykułów, ksiażek i raportów. Cały przebieg rozmowy reguluje zasada autora: wypowiada się doświadczony ekspert, związany z poprzednim rządem, ceniony na świecie, a więc głos prawomocny w polu formacji dyskursywnej, do której należy ten wywiad. Pierwsza część dotyczy zdecydowanie pozytywnej oceny reformy z 1999 roku, która wprowadzała gimnazja, druga część służy podważaniu zasadności obecnej reformy, trzecia prezentuje zalecenia eksperta odnośnie systemu oświaty, z akcentem położonym na rolę kształcenia ogólnego. W całej rozmowie ważnymi punktami odniesienia są Francja, Holandia i kraje skandynawskie jako wzór organizacji oświaty dla Polski (i wzór postępu cywilizacyjnego); badania PISA, prezentowane tu (w przeciwieństwie do przykładu 1) jako dowód na edukacyjny sukces gimnazjów; oraz katalog kompetencji ogólnych, które zdaniem eksperta młodzi Polacy powinni zdobyć, zwłaszcza transversal skills, czyli umiejętności przydatne w wielu zawodach (na przykład zdolność do samorozwoju, uczenia się przez całe życie, pracy projektowej). Spotykają się tu elementy neoliberalnego dyskursu edukacyjnego, z kreśleniem opozycji Centrum-Peryferia i z normalizującym projektem społecznym artykułowanym w polu dyskursu eksperckiego (por. Tomanek, 2012: 111).

Analizie poddano wypowiedź ze środkowej części rozmowy, wpisującą spór o gimnazja w kontekst polityczny i jawnie odnoszącą się do określonego porządku wiedzy. 


\section{Czemu gimnazja tak przeszkadzają rządzącym?}

- Myślę, że interes polityczny i ideologia są tu najważniejsze. Ze znanych mi ekspertów czy też naukowców zajmujących się badaniami edukacji nikt nie jest za likwidacją gimnazjów i skróceniem okresu kształcenia ogólnego. Z tego, co wiem, reformę wspierają tylko były minister prof. Legutko i wykładowca z Krakowa prof. Waśko. Choć oni tak naprawdę ekspertami od reform edukacyjnych nie są. Jeden jest specjalistą od filozofii, drugi od języka polskiego. Mają zakodowane i mocno wbite w głowę, że gimnazja nie działają. Ale żadnych badań na to nie mają, bo ich nigdy nie robili. Ich interesuje wprowadzenie „zdrowej” ideologii do programów nauczania, a przy tym widoczny jest też ich sentyment do PRL-owskiego systemu, gdzie do liceów, a tym bardziej na studia, szła tylko elita.

Ta antyreforma ma też przynieść wymierne korzyści polityczne. Spowoduje olbrzymi zamęt tuż przed wyborami samorządowymi. Niezbędne będą masowe zwolnienia nauczycieli, bo inaczej na przykład samorządy wiejskie po prostu zbankrutują. Nie ma możliwości, żeby gmina wiejska przeżyła w spokoju sytuację, gdy zabraknie jej jednej dziewiątej subwencji oświatowej, a będzie zmuszona do zatrudnienia tej samej liczby nauczycieli. Ten cel polityczny, czyli zamęt przed wyborami samorządowymi, a przy tym okazja do wymiany kadr dyrektorskich i nauczycielskich w szkołach, może podobać się kierownictwu PiS. To jedyne racjonalne wytłumaczenie, dlaczego partia rządząca tak upiera się przy tych zmianach.

I tym sposobem minister Zalewska przygotowuje zmiany w ogóle nieadekwatne do dzisiejszych potrzeb. Cokolwiek by ta ekipa mówiła, to jest powrót do PRL-u. Centralizacja zarządzania oświatą, powrót starej struktury szkolnej, a do tego regres w myśleniu o nauczaniu.

Wszyscy mają uczyć się tego samego, w tym samym czasie, zakresie. Mają zapamiętywać fakty, uczyć się historii, wielkich wierszy na pamięć. Do tego wycofują się z przedmiotów przyrodniczych. Pani minister je zabija! Skasowanie sprawdzianu z tych przedmiotów po szkole podstawowej oznacza, że dzieciaki w ogóle nie będą się ich uczyć. Bo po co? Jeśli to się stanie, to nie mamy szans na innowacyjną gospodarkę za 20 lat.

Ta ekipa traktuje nauczycieli jak biurokratów, którymi trzeba zarządzać, a uczniów jak małe dzieci. Proponowane zmiany zmierzają do odebrania autonomii szkole. A obawiam się, że następnym krokiem będzie odebranie władzy samorządom. (Suchecka, 2016)

Wypowiedź, ukierunkowana pytaniem dziennikarki, rozpoczyna się od pejoratywnej diagnozy politycznej i ideologicznej motywacji stojącej za projektem reformy edukacji. Kluczowym argumentem za taką klasyfikacją działań rządzących jest odwołanie się do opinii anonimowych, ale znanych podmiotowi mówiącemu "prawdziwych” naukowców i ekspertów od edukacji, z grona których wykluczani są akademicy wspierający zmiany jako reprezentanci dyscyplin wiedzy nieadekwatnych do prawomocnego wypowiadania się w kwestii gimnazjów. Można powiedzieć, że podstawą dla tej argumentacji są zewnętrzne procedury kontroli dyskursu, polegające między innymi na wykluczeniu określonych głosów poprzez odmowę przywileju mówienia wobec określonych typów podmiotów. Naukowcy zaszeregowani jako prorządowi są wykluczani z prawomocnego pola dyskursu także w oparciu o kreślenie opozycji prawdy i fałszu (ekspert musi 
mówić „prawdę” przeciw fałszowi politycznej ideologii, zakorzenionej w ustroju komunistycznym). Następnie akcentowane są zagrożenia, które zdaniem eksperta niesie ze sobą reforma PiS, związane z organizacyjno-ekonomicznymi konsekwencjami nowego systemu oświaty. W pewnej mierze naznacza tę wypowiedź także opozycja rozumu i szaleństwa. Twierdzi się bowiem, że nie można racjonalnie uzasadnić planowanej zmiany, bo przyniesie ona zamęt i masowe zwolnienia nauczycieli, zwłaszcza na wsi. Zatem musi za nią stać motywacja irracjonalna z punktu widzenia społeczeństwa, ale będąca elementem polityczno-szaleńczego planu rządzącej partii. Potem prezentowany jest projekt antypodmiotu ucznia, który w nowej szkole będzie edukowany w sposób regresywny, odtwórczy, jednolity i hamujący fetyszyzowaną w neoliberalnym dyskursie edukacyjnym innowacyjna gospodarkę. Jednocześnie wskazywane jest uprzedmiotowienie nauczycieli i uczniów jako obiektów dyscyplinarnego rządzenia, któremu w dalszej części wywiadu jest przeciwstawiana wizja niedyrektywnego, elastycznego rządzenia młodzieżą i pedagogami.

\section{Przykład 3}

O ile dwie poprzednie wypowiedzi zawierały już na poziomie realizacji językowych wyraźne przesłanki do krytyki postfoucaultowskiej, o tyle ten przykład nie wydaje się tak klarowny. Jest to list Sławomira Broniarza, prezesa Związku Nauczycielstwa Polskiego, skierowany do rodziców dzieci w wieku szkolnym przed ogólnopolskim strajkiem nauczycieli przeciw reformie edukacji, zaplanowanym na 31 marca 2017 roku . Według danych organizatorów wzięło w nim udział 37\% placówek szkolnych w Polsce, co czyni go najliczniejszym od 2007 roku. Jednak zdaniem MEN do protestu włączyło się kilkakrotnie mniej szkół (11\%), ponadto poparcia nie udzielił mu drugi największy związek zawodowy nauczycieli i pracowników oświaty NSZZ „Solidarność”. Celem poniższego listu jest uzyskanie wsparcia rodziców dla strajku poprzez hasłowe i emocjonalne wskazanie określonych racji. Proponuję spojrzeć na tę wypowiedź w szerokim kontekście relacji władzy regulujących spór o gimnazja.

Drodzy Rodzice!

W piątek, 31 marca 2017 roku pracownicy oświaty przyjdą do szkół, ale nie będą pracować. Strajkujemy, bo zależy nam na edukacji i przyszłości naszego zawodu.

Zdecydowaliśmy się na ten niełatwy dla nas - wychowawców - krok, wiedząc, że strajk pracowników oświaty może skomplikować Wam życie rodzinne i zawodowe. Jednak to będzie tylko

${ }^{4}$ Oficjalne postulaty dotyczyły żądań płacowych i gwarancji zatrudnienia, impulsem do organizacji strajku były jednak obawy związane z następstwami likwidacji gimnazjów. 
jeden dzień. Tymczasem reforma edukacji spowoduje wieloletni chaos, bo nie polega tylko na likwidacji gimnazjów. Jej negatywne skutki odczują wszyscy: od trzylatków, dla których zabraknie miejsc w przedszkolach po uczniów ostatnich klas szkoły podstawowej i gimnazjalistów. Jak podkreślają rodzice z koalicji „Nie dla chaosu w szkole”, w tej zmianie nie chodzi o dobro uczniów.

Drodzy Rodzice,

w imieniu strajkujących nauczycieli i pracowników oświaty proszę o zrozumienie naszej decyzji. Wspierajcie nas 31 marca! Bądźcie z nami! (Broniarz, 2017)

Wypowiedź utrzymaną w nieoficjalnej i mobilizacyjnej modalności rozpoczyna wyjaśnienie przebiegu strajku i uznanie jego problematycznych skutków dla rodzin w dniu protestu. Te racjonalizowane są jednak ,konsekwencjami dziejowymi”, które ma przynieść reforma: wieloletni chaos dotykający wszystkie uczące się dzieci i ich rodziców, niepewną przyszłość zawodu nauczyciela i edukacji jako takiej. Z uwagi na wydźwięk tej wypowiedzi, alarmistyczny i demaskatorski, a także kontekst momentu sporu, w jakim zaistniała (parę miesięcy po uchwaleniu ustawy Prawo oświatowe, a w konsekwencji sprowadzeniu protestów do działań „beznadziejnych"), można rozpatrywać parezjastyczny wymiar tego głosu polegający na mówieniu prawdy, która w tym przypadku ma być ukrywana przez rządzących, a ujawniana przez nauczycieli i rodziców: nie chodzi o dobro uczniów. Odnosząc ten głos do centralnej w ostatnich wykładach Foucaulta kategorii parezji, trzeba zaznaczyć, że nie ma tutaj radykalnego jej wariantu związanego z ryzykiem, niekiedy wręcz cielesnym, jakie ponosi mówiący własną, niechcianą prawdę o rzeczywistości. Byłby to raczej przykład quasi-parezji czy współczesnej parezji politycznej, egzekwowania (demokratycznego) prawa do mówienia pewnej prawdy, niewygodnej dla władzy politycznej, gdzie jednocześnie akt mówienia tej prawdy oznaczałby zajęcie stanowiska w polu politycznym (por. Foucault, 2008: 141). $\mathrm{W}$ wypowiedzi tej można widzieć narzędzie wprowadzania do dyskursu publicznego konkurencyjnej (wobec rządowej) wiedzy i prawdy o przedmiocie sporu.

W warstwie metadyskursywnej występują zbieżności między formacjami, roboczo nazwanymi na potrzeby tej analizy, ministerialną i związkową. Obie projektują model podmiotu współpracującego rodzica, zatroskanego o przyszłość dziecka, a także uprzedmiotawiają uczniów poprzez wpisanie ich losu w określoną wizję edukacji i społeczeństwa oraz odebranie - jako dzieciom - prawa do mówienia we własnej sprawie. Można zaryzykować stwierdzenie, iż mimo przeciwnych celów strategicznych, które przyświecającą tym formacjom, są one wytworem zbliżonego reżimu prawdy. Łączy się on $\mathrm{z}$ wezwaniem do mówienia prawdy o społeczeństwie poprzez pryzmat tego, jak jest/ma być rządzona młodzież i jaki projekt podmiotu powinna realizować dla społeczeństwa, gospodarki, narodu (treściowo 
ta „prawda” może być każdorazowo inna, ale tu chodzi o mechanizm samego aktu prawdy). Na takim reżimie prawdy wydaje się też ufundowany neoliberalny dyskurs edukacyjny. Formację związkową od ministerialnej czy eksperckiej odróżnia słaba obecność odniesień gospodarczo-optymalizacyjnych (jak na przykład idea gospodarki opartej na wiedzy i innowacji). Jednak wykluczenie czy marginalizacja tych pojęć i kwestii w ramach tej formacji nie oznacza jej autonomii. Przeciwnie, takie niezgodności można w perspektywie postfoucaultowskiej czytać jako element gry toczonej w obszarze sporu.

\section{Podsumowanie}

Nie ma tutaj miejsca na szczegółowe omawianie wniosków z warsztatowej analizy pozostałych wypowiedzi. Trzeba jednak zasygnalizować kierunek ogólnej refleksji z niej płynącej. Większość analizowanych wypowiedzi, choć różni się modalnością i celem strategicznym, „mówi” podobnym słownikiem pojęć, do którego należą między innymi dobro dzieci, podmiotowość, szanse edukacyjne, innowacje, efektywność, przyszłość społeczeństwa, badania, testy PISA. Stanowią one elementy dyskursu osadzonego w szerszej wiedzy o świecie, niż ta dotycząca bezpośrednio szkoły. Wiele z nich jest ugruntowanych racjonalnością ekonomiczną, owszem - zhumanizowaną, akcentującą afekty indywidualne i zbiorowe, ale jednak związaną z postulatem określonej formy rządzenia populacją poprzez wytwarzanie podmiotów mniej lub bardziej subtelnie kierowanych ku dość stabilnemu katalogowi cech, które należy posiąść dla dobra własnego i ogółu. W dynamicznym polu sporu dochodzi do licznych przecięć i cyrkulowania formacji dyskursywnych. Natomiast różnicuje je zarówno polityczna afiliacja, jak i użytek czyniony z wiedzy naukowej i potocznej oraz miejsce lub jego brak dla odniesień narodowych i kolektywnych.

Zasadniczym podmiotem planowanej zmiany w edukacji lub oporu przeciw niej są rząd centralny, samorządy, nauczyciele oraz rodzice, stawiający opór i mobilizowani do poparcia tej czy innej strony sporu. Gdzie w tej konstelacji jest miejsce dla nastolatków, obecnych lub niedoszłych gimnazjalistów? W funkcji ucznia, czasami dziecka, a więc w kategoriach demograficzno-pedagogicznych, zaś bardzo rzadko jako podmiot mówiący (w analizowanym zbiorze znalazł się tylko jeden materiał o młodzieży broniącej swojego gimnazjum zawierający wypowiedzi uczniów). W świetle wiedzy regulującej spór o gimnazja uczniami trzeba rządzić, troszczyć o nich, ale jednocześnie stanowią oni grupę najsilniej wykluczoną z produkcji dyskursu, w którym tyle się o nich mówi. Prawda czy raczej prawdy 
wyłaniające się z wypowiedzi wytwarzanych w sporze o gimnazja niosą ze sobą diagnozę kryzysu polskiej edukacji lub ryzyka bądź zagrożenia związanego z jej reformą, którym należy przeciwdziałać. Formy naprawy/przeciwdziałania są jednak także problematyczne i budzące opór, a w czasie gdy powstaje ten artykuł, spór o gimnazja wciąż trwa.

Podsumowując zebrane tu propozycje i uwagi metodologiczne, trzeba przypomnieć, że podstawowym zadaniem postfoucaultowskiej analizy dyskursu jest jego badanie $\mathrm{w}$ relacji do problematyki władzy, wiedzy i podmiotu, a także próba wyłuskania reguł i uwarunkowan, reglamentujących wytwarzanie dyskursu, poprzez co ukierunkowuje się i zawęża spektrum pojmowania i klasyfikowania społecznego doświadczenia oraz spektrum podejmowanych praktyk. Pełniejszą realizację tych celów umożliwiałaby mikroanaliza ( $w$ ścisłym tego słowa znaczeniu) zgromadzonych materiałów. Wymaga ona uzupełnienia rozważań prowadzonych z pomocą kategorii Foucaulta takimi technikami badania tekstu, które nie stoją w sprzeczności do jego ogólnej koncepcji dyskursu. Można się tu posiłkować między innymi analizami lingwistycznymi, analizą retoryczną, argumentacyjną, narracyjną lub konwersacyjną - i takie próby są już czynione (między innymi Baxter, 2002, Nowicka-Franczak, 2017b). Ponadto badanie powinno opierać się nie tylko na bardziej przekrojowym i wyczerpującym zbiorze materiałów empirycznych, ale także obok analizy synchronicznej (której wycinkiem jest powyższa prezentacja) uwzględniać analizę diachroniczną dynamiki badanego dyskursu czy sporu. Wartym rozważenia krokiem jest otwarcie się na wzmiankowaną analizę dyspozytywu i rozszerzenie zbioru danych o te dotyczące codziennych praktyk edukacyjnych i komunikacyjnych w gimnazjach, ich infrastruktury, organizacji pracy i przestrzeni oraz symboliki tam obecnej.

Słabością postfoucaultowskiej analizy dyskursu jest to, że jej niewystandaryzowany charakter może przekładać się na arbitralność wielu decyzji badacza i skłaniać, by dopasowywać materiały do z góry założonej tezy. W tym przypadku testem dla wyborów badacza może być znowu użycie instrumentarium mikroanalizy retorycznej, konwersacyjnej etc. do krytycznej weryfikacji wniosków. Deficytem optyki postfoucaultowskiej jest także bardzo powierzchowne zainteresowanie afektywnym wymiarem dyskursu i relacji władzy, czyli jedną z centralnych kwestii dla pedagogiki. Stosunkowo od niedawna problem emocji jest podejmowany przez badaczy postfoucaultowskich - wciąż raczej jako postulat badawczy niż jego pełna realizacja (por. Maesse, 2011).

Analiza postfoucaultowska nie rozstrzyga, kto ma rację w sporze, kto mówi prawdę, kto wypowiada się etyczny sposób. Dla części badaczy będzie to źródłem niedosytu, dla innych atutem tej perspektywy, gdyż unika ona dyrektywnego 
moralizowania, a więc tego aspektu dyskursów o edukacji i wychowaniu, które są w tej optyce jednym z głównych przedmiotów krytyki. Bodaj największą zaletą omawianej tu perspektywy jest to, że zmusza ona do rozumowania „pod włos”, do przekraczania myślenia w kategoriach binarnych opozycji, dychotomii władzy i uczula na strategiczny wymiar całości komunikacji społecznej. Najtrudniejszym wyzwaniem jest natomiast postawa zdystansowania i pewnej nieufności wobec wniosków z prowadzonych analiz. Warto bowiem mieć na uwadze, że nie są to ustalenia ostateczne i pewne, które nie mogłyby zostać poddane krytyce i podważone, także w oparciu o podobną optykę analityki władzy. Również ta skromna warsztatowa propozycja jest tylko jednym z możliwych postfoucaultowskich spojrzeń na polski spór o gimnazja.

\section{Literatura}

Audureau J.-P. (2003). Assujettissement et subjectivation: réflexions sur l'usage de Foucault en éducation. „Revue Française de Pédagogie” nr 143.

Bacchi C., Bonham J. (2014). Reclaiming discursive practices as an analytic focus: political implications. „Foucault Studies” nr 17.

Ball S.J. (1992). Foucault i edukacja. Dyscypliny i wiedza. Kraków.

Baxter J. (2002). Competing discourses in the classroom: a post-structuralist discourse analysis of girls' and boys' speech in public contexts. „Discourse \& Society” nr 13(6).

Bublitz H., Bührmann A.D., Hanke Ch., Seier A. (red.) (1998). Das Wuchern der Diskurse. Perspektiven der Diskursanalyse Foucaults. Frankfurt-New York.

Bührmann A.D., Diaz-Bone R., Gutiérrez Rodriguez E., Kendall G., Schneider W., Tirado F.J. (2007). „Forum Qualitative Sozialforschung: From Michel Foucault’s Theory of Discourse to Empirical Discourse Research" nr 8(2).

Bührmann A.D., Schneider W. (2007). More than just a discursive practice? Conceptual principles and methodological aspects of dispositif analysis. „Forum Qualitative Sozialforschung: From Michel Foucault's Theory of Discourse to Empirical Discourse Research" nr 8(2), art. 28.

Chutorański M. (2013). Pojęcie i konteksty wychowania w pracach Michela Foucaulta. Wrocław.

Czyżewski M. (2013a). Polityki publiczne w optyce postfoucaultowskiej. Zarys perspektywy badawczej.

[W:] A. Wojciuk (red.). Analiza polityki publicznej. Podejścia teoretyczno-metodologiczne. Warszawa.

Czyżewski M. (2013b). W kręgu społecznej pedagogii. „Societas/Communitas” nr 2(16).

Donzelot J., Gordon C. (2005). Comment gouverner les sociétés libérales?. „Esprit” nr 11.

Elden S. (2016). Foucault's Last Decade. London.

Fisch M. (2011). Werke und Freuden. Michel Foucault - eine Biografie. Bielefeld.

Foucault M. (1980). Question on geography. [W:] M. Foucault. Power/Knowledge. Selected Interwievs and Other Writings 1972-1977. New York.

Foucault M. (1995). Historia seksualności. Warszawa.

Foucault M. (1998). Podmiot i władza. „Lewą Nogą” nr 10. 
Foucault M. (2000). Czym jest Oświecenie?. [W:] M. Foucault. Filozofia, historia, polityka. Wybór pism. Warszawa-Wrocław.

Foucault M. (2001 [1976]). Le discours ne doit pas être pris comme... [W:] M. Foucault. Dits et écrits II. 1976-1988. Paris.

Foucault M. (2002). Porządek dyskursu. Gdańsk.

Foucault M. (2008). Le gouvernement de soi et des autres. Cours au Collège de France. 1982-1983. Paris.

Foucault M. (2010). Bezpieczeństwo, terytorium, populacja. Wykłady w Collège de France 1977-1978. Warszawa.

Foucault M. (2011). Narodziny biopolityki. Wykłady w Collège de France 1978-1979. Warszawa.

Foucault M. (2012). Hermeneutyka podmiotu. Wykłady w Collège de France 1981-1982. Warszawa.

Foucault M. (2013). Etyka troski o siebie jako praktyka wolności. [W:] M. Foucault. Kim pan jest, profesorze Foucault? Debaty, rozmowy, polemiki. Kraków.

Foucault M. (2014). Rządzenie żywymi. Wykłady w Collège de France 1979-1980. Warszawa.

Gehring P. (2009). Nachwort. [W:] M. Foucault. Geometrie des Verfahrens. Schriften zur Methode. Frankfurt am Main.

Gehring P. (2012). Abseits des Akteurs-Subjekts. Selbsttechniken, Ethik als politische Haltung und der Fall der freimütigen Rede. [W:] R. Keller, W. Schneider, W. Viehöver (red.). Diskurs-Macht-Subjekt. Theorie und Empirie von Subjektivierung in der Diskursforschung. Wiesbaden.

Gromkowska-Melosik A. (2004). Społeczne konstruowanie kobiecości i męskości w kulturach: wiktoriańskiej i globalnej. Kraków.

Hunter I. (1994). Rethinking the School. Subjectivity, Bureaucracy, Criticism. St. Leonards.

Klemm J., Glasze G. (2005). Methodische Probleme Foucault-inspirierter Diskursanalysen in den Sozialwissenschaften, „Forum Qualitative Sozialforschung” nr 6(2), art. 24.

Klus-Stańska D. (2015). Wyjść poza reżim imperatywu rozwojowego. Między inspiracjami Rousseau a wplywem myśli Foucaulta na wspótczesne studia nad dzieciństwem. „Problemy Wczesnej Edukacji" nr 1(28).

Koller H.-Ch., Lüders J. (2004). Möglichkeiten und Grenzen der Foucaultschen Diskursanalyse. [W:] N. Ricken, M. Rieger-Ladich (red.). Michel Foucault: Pädagogische Lektüren. Wiesbaden.

Maesse J. (2011). Bilder, guter Kindheit' in Regierungsdokumenten. Endbericht einer Diskursanalyse. „Educare Working Paper” nr 2.

Marshall J.D. (1996). Michel Foucault. Personal Autonomy and Education. Dordrecht.

Melosik Z. (2009). Uniwersytet i społeczeństwo. Dyskursy wolności, wiedzy i władzy. Kraków.

Melosik Z. (2013). Kultura popularna i tożsamość młodzieży. W niewoli władzy i wolności. Kraków.

Mendel M. (2007). Społeczeństwo i rytuał. Heterotopia bezdomności. Toruń.

Męczkowska-Christiansen A. (2006). Podmiot i pedagogika. Od oświeceniowej utopii do pokrytycznej dekonstrukcji. Wrocław.

Nowicka M. (2011). „Urządzenie”, „zastosowanie”, „układ”... - kategoria dispositif u Michela Foucaulta, jej tłumaczenia i ich implikacje dla postfoucaultowskich analiz władzy. „Przegląd Socjologii Jakościowej" nr 7.

Nowicka M. (2016). O użyteczności kategorii dyspozytywu w badaniach społecznych. „Przegląd Socjologii Jakościowej" nr 1.

Nowicka-Franczak M. (2017a), Postfoucaultowska analiza dyskursu. Przypadek sporu o Jedwabne. [W:] M. Czyżewski, M. Otrocki, T. Piekot, J. Stachowiak (red.). Analiza dyskursu publicznego. Przegląd podejść i metod. Warszawa. 
Nowicka-Franczak M. (2017b). Niechciana debata. Spór o książki Jana Tomasza Grossa. Warszawa.

Ostrowicka H. (2012). Urządzanie młodzieży. Studium analityczno-krytyczne. Kraków.

Ostrowicka H. (2015a). O badaniach „pedagogizacji życia społecznego” kilka słów z poznawczej perspektywy pedagogiki ogólnej. „Nauki o Wychowaniu. Studia Interdyscyplinarne” nr 1.

Ostrowicka H. (2015b). Przemyśleć z Michelem Foucaultem edukacyjne dyskursy o młodzieży. Dyspozytyw i urządzanie. Kraków.

Othmer J., Weich A. (red.). (2015). Medien-Bildung-Dispositive: Beiträge zu einer interdisziplinären Medienbildungsforschung. Wiesbaden.

Pongratz L.A. (1989). Pädagogik im Prozess der Moderne. Studien zur Sozial- und Theoriegeschichte der Schule. Weinheim.

Pongratz L.A., Wimmer M., Nieke W., Masschelein J. (red.). (2004). Nach Foucault. Diskurs- und machtanalytische Perspectiven der Pädagogik. Wiesbaden.

Ricken N., Rieger-Ladich M. (red.). (2004). Michel Foucault. Pädagogische Lektüren. Wiesbaden.

Ristić D., Marinković D. (2016). The disciplinary society and the birth of sociology: A Foucauldian perspective. „Družboslovne Razprave” nr 83.

Rose N. (1999). Powers of Freedom: Reframing Political Thought. Oxford.

Sarasin Ph. (2003). Geschichtswissenschaft und Diskursanalyse. Frankfurt am Main.

Schneider W. (2015). Dispositive überall und nirgendwo? Anmerkungen zur Theorie und methodischen Praxis der Dispositivforschung. [W:] J. Othmer, A. Weich (red.). Medien-Bildung-Dispositive: Beiträge zu einer interdisziplinären Medienbildungsforschung. Wiesbaden.

Simons M., Masschelein J. (2006). The learning society and governmentality: an introduction. „Educational Philosophy and Theory" nr 4.

Simons M., Masschelein J. (2008). The governmentalization of learning and the assemblage of a learning apparatus. „Educational Theory” nr 58(4).

Tomanek P. (2012). Ujarzmienie czy legitymizacja? Normalizacyjne aspekty dyskursów eksperckich. „Studia Socjologiczne” nr 1.

\section{Analizowane materiały}

Broniarz S. (2017). List Prezesa ZNP do Rodziców, http://www.znaprzykładedu.pl/element/3034/

List_Prezesa_ZNP_do_Rodzicow.

Suchecka J. (2016). Ekspert: Bez gimnazjów skrzywdzimy najsłabsze dzieci. Wygra na tym bogata elita. Wywiad z dr. Maciejem Jakubowskim „Gazeta Wyborcza”, 18.10.2016.

Uzasadnienie (2016). https://legislacja.rcl.gov.pl/docs//2/12289958/12379225/.../dokument253146. pdf. 